\title{
Verden rundt uden hat
}

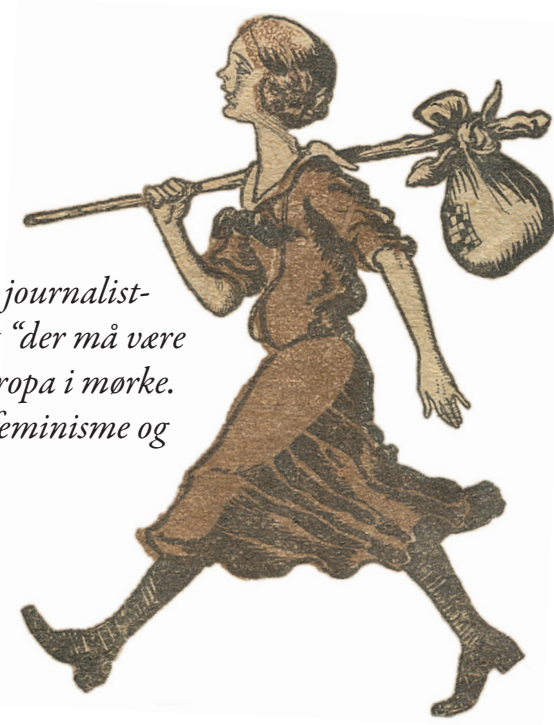

I 1920 sender Berlingske Tidende den kun 20-årige journalistspire Estrid Ott ud på jordomrejse. Avisen mener, at "der må vare håb et sted", efter Forste Verdenskrig har henlagt Europa i morke. Ott skulle vise sig at udfordre både måden at tanke feminisme og konsrollerpa:

afforskningsstipendiat, dr.phil. Lotte Thrane, Det Kongelige Bibliotek

I

1928, hundredåret for Jules Vernes fødsel, sendte et dansk dagblad den 15-årige Palle Huld verden rundt. Det var Viggo Cavling, redaktør på Politiken, der fik ideen. Det unge menneske skulle slå rekorden fra Vernes roman Jorden rundt $i 80$ dage. Det blev der skrevet mange historier til avisen om, og Palle skrev også selv en bog med titlen Jorden rundt paa 44 Dage. Den blev genudgivet i 2012, hvor Palle Huld ville være fyldt 100 år.

Hvad de færreste ved er, at ideen med at sende et ungt menneske verden rundt i PR-øjemed var genbrug. Det havde Politikens konkurrent Berlingske Tiden$d e$ allerede gjort 1920-21 - og her taler vi ovenikøbet om en ung kvinde.

I 1920 er der nu ikke noget jubilæum at fejre. Europa vånder sig over følgerne af Den Store Krig, historiens første verdenskrig. Danmark deltog ganske vist ikke aktivt, men netop derfor kunne mange tjene godt på at levere landbrugsvarer mad! - til de krigsførende nationer, og det gav andre moralske tømmermænd. I 1920 er verden på alle måder forandret, både fysisk og mentalt - nye grænser trukket, magtcentre flyttet, magtbalancer ændret. Det kulturchok, de nye erkendelser medførte, var med til at svække forældregenerationens tillid til fremtiden; en form for duknakket resignation var udbredt.

"Kan det virkelig passe", diskuterede de på avisredaktionerne, mens pessimismen bredte sig yderligere - "er der slet ikke nogle positive historier?” Så er det, at en vaks redaktør foreslår at sende et ungt menneske ud på en lang rejse for at opleve og beskrive verden, som den tager sig ud netop nu, set med unge øjne. For der $m a ̊$ være håb et sted.

\section{Morgendagens generation}

Redaktørens håb knyttede an til en tidstypisk interesse for børn og ungdom, for 'morgendagens generation', der voksede frem i disse år, sideløbende med pessimismen. Blikket blev her rettet mod det vitale eller det oprindelige i mennesket, og helst i en form, der endnu var uspoleret af 'kulturen'. Denne interesse for det oprindelige gik udmærket hånd $\mathrm{i}$ hånd med begejstring for teknologi efter amerikansk mønster - biler, flyvemaskiner, film - alt, hvad der bevægede sig, og helst hurtigt. 
bedste fod med Georg Brandes. Forældrene var fordomsfri kulturradikale med en omgangskreds, der rummede politikere som P. Munch og C.N. Starcke, iværksættere som Egmont H. Petersen, kulturpersonligheder som Brandes-brødrene, kunstnere som Karin og Sophus Michaëlis og Herman Bang - og eventyrere som grønlandsfarerne Mylius-Erichsen og Knud Rasmussen.

\section{It det valgte Berlingske Tidende at $A$ se gennem fingre med, for frøken 1 Ott var også berømt som sig selv} og kunne kalde sig forfatter; hun havde allerede fået udgivet tre bøger - heriblandt den pædagogiske utopi Nisseriget (1917), der i dag er optaget i Den Store Danske Kanon. Og så var hun spejder - i absolut opposition til og hånet af sin radikale familie. Det var den vigtigste grund til, at avisen valgte hende.

Her er man nok blevet prikket på skulderen af den kontroversielle spejderchef, ritmester Cay Lembcke, hvis synspunkter Berlingske gerne gav spalteplads. Det skal have været hans idé at sende unge Estrid verden rundt $-i$ spejderuniform som repræsentant for Det Nye Menneske. Spejderne, mente han, skulle være frontkæmpere i krigen mod "slaphed og dekadence" - i hans øjne den største trussel mod det nationale fællesskab i 1920.

Estrid Ott, der allerede som ung kunne karakteriseres som en snarrådig, handlekraftig og stærk ener - altså Lembckes nye menneskeideal - var nu især fascineret af det, man kunne kalde spejderbevægelsens feministiske potentiale, nemlig det spejderlivet kunne tilbyde piger og unge kvinder: Et aktivt, udadvendt liv med masser af fysisk aktivitet og muligheder for at lære at færdes i naturen og i verden, helt på egen hånd. At være på lige fod med de unge mænd, med andre ord. Det var ikke daglig kost for borgerskabets unge piger i begyndelsen af det 20. århundrede. Hun tog derfor uden betænkning mod Berlingske Tidendes tilbud - mens hendes Politiken-læsende familie knurrede.

\section{En radikal går enegang}

Estrid Ott var en ganske sammensat person, men hun var hele livet "radikal i sit hjerte", som hun selv udtrykte det, og desuden medlem af partiet. Påvirkningen hjemmefra må have været effektiv, for allerede i 1915, hvor hun selv var 15, og hvor Første Verdenskrig buldrer løs i Europa, interviewer hun Politikens teaterkritiker Sven Lange om hans rolle som fredsaktivist i Ford-ekspeditionen, en uofficiel, men økonomisk velpolstret amerikansk fredsbevægelse, der var organiseret af den ungarske pacifist og kvindesagsforkæmper Rosika Schwimmer og finansieret af bilfabrikanten Henry Ford.

De to ankom til Oslo sammen med 30 andre velhavende fredsaktivister december 1915 på en chartret atlanterhavsdamper, og planen var at sejle rundt i Europa og agitere for en fredskonference - under overskriften Our Soldiers out of the Trenches Before Christmas. Organisatorisk inkompetence og en influenzaepidemi om bord satte dog en stopper for planen.

Estrid Otts mor, forfatteren Olga Ott, var sammen med veninden og kollegaen Karin Michaëlis også stærkt engageret i fredssagen: Karin Michaëlis med filantropisk arbejde i Wien, Olga Ott med to enaktere, De Vaabenlose og Du skal are (1916), hvor hun kritiserer dansk neutralitet og gullaschbaronerne, der tjente mange penge på neutraliteten. 
Bølgerne er med garanti gået højt omkring middagsbordet i det Ott'ske hjem under krigen.

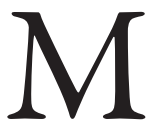
en nu har vi 1920, og Estrid er 20, og hun vil ud i verden. Rejseprojektet blev døbt Verden rundt uden Hat, en både mystificerende og provokerende titel. Ideen kom hverken fra avisen eller fra spejderchefen, den var unge Estrids helt egen. At rejse "uden hat" var en understregning af, at det drejede sig om en moderne, ung kvinde, der optrådte naturligt og ukonventionelt. Her tænktes også på spejderuniformen, som hun skulle bære, ikke i paradesammenhæng (hvor hat var påkrævet), men som en del af hendes rejseliv, hvor kittelkjolen med de mange lommer var praktisk og funktionel. Samtidig skulle den mildt sagt kønsneutrale påklædning fungere som beskyttelse, som visitkort og altså også som reklame.

Potentielle medlemmer skulle overbevises og hverves undervejs.

Rejsen kom til at vare et år og gik på kryds og tværs gennem USA, og via Hawaii videre til Japan, Kina og Manchuriet. Sidste stop var Vladivostok, hvorfra hun sejlede hjem på et af ØK's skibe. Estrid holdt foredrag på engelsk undervejs om spejderbevægelsen og skrev et antal artikler til Berlingske Tidende, så det var bestemt ikke nogen ferie.

\section{Herman Bangs fodspor}

Det er interessant at sammenligne hendes historier med den fem år yngre Palle Hulds beskrivelser af verden. Hvor han først og fremmest er den frejdige, nysgerrige og opvakte dreng, der skriver i bedste dansk stil-tradition, markerer Estrid Ott sig allerede her som en professionel reporter. Hendes nysgerrighed er lige så åben- øjet og fordomsfri som Palles, men man mærker, at hun også har lært et håndværk, at hun kan vælge i sit stof, og at hun kan perspektivere. Og måske har hun skelet til en af husvennerne fra barndomshjemmet, Herman Bang, der for Nationaltidende havde beskrevet Christiansborgs brand 4. oktober 1884.

Stoffet til Otts første artikel bød sig til, så at sige, da anarkister sprænger flere bomber i Wall Street 16. september 1920, netop den dag hun ankom til byen, så hun med det samme kunne skrive en impressionistisk on the spot-reportage. Mesterstykket er dog beretningen fra Vladivostok, hvor hun 25. juli 1921 sammenfatter sine oplevelser i byen, der blev centrum for den russiske revolutions sidste opgør mellem de røde og hvide:

\section{$\boldsymbol{\zeta}$ Vladivostock er nu under japansk} Overkontrol. Revolutionen er forbi. Var jeg kommet blot et Par Dage tidligere, kunde jeg have overvaret de vilde Kampe i Gaderne.

$$
\text { I Vladivostock taler man om den }
$$
bvide - ikke om den rode Fare. Udenfor Byen gor Resterne af tre opløste Hare Omegnen usikker. Man mener, der er omkring 10.000 Mand, og de skal alle leve. Plyndringer og Overfald horer til Dagens Orden. Ingen ved sig sikker. Naar Folk flytter paa Landet, regner de med at blive overrumplet $i$ det mindste én Gang i Løbet af Sesonen; derfor lader de alle Verdisager blive i Byen. Ledende Forretningsfolk bliver "kidnapped" og fort til et lille Hus, dybt inde i de magtige Skove, hvor de bliver behandlet og bevertet, indtil de loslades, naar den onskede Løsesum udbetales. En Hustru, der ikke kunde betale, fik forst sendt sin Mands Finger og derpaa bele Haanden. 


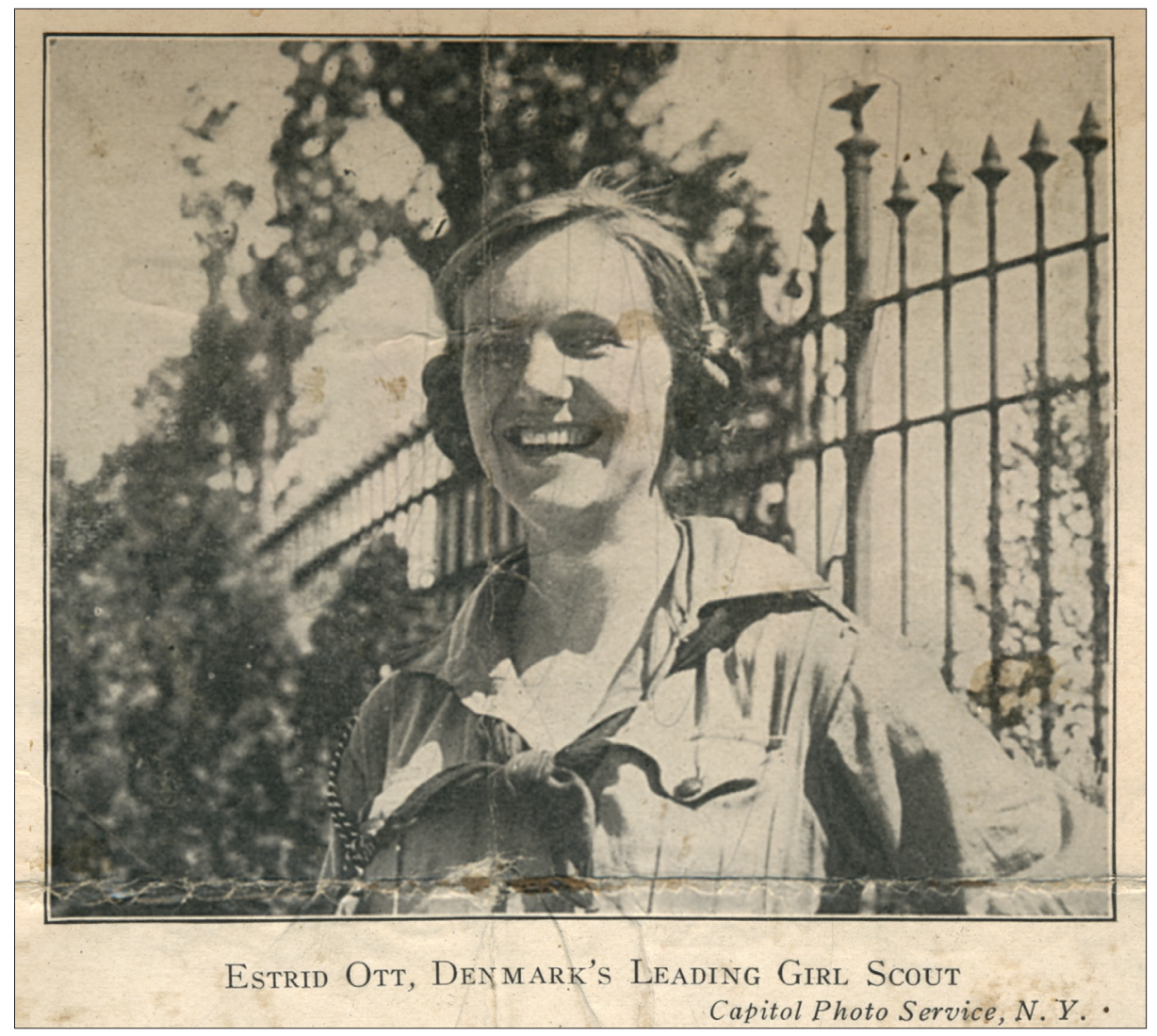

Estrid Ott var massivt presseopdakket på det meste af rejsen. Her et billede fra New York Times, som kalder hende "Denmark's Leading Girl Scout". Udklip fra scrapbogen.

Der er hverken Ro, Orden eller Disciplin i Harene. Nu og da, naar en god Taler - ved Hjalp af rigeligt Brandevin og Løfter om stor Belonning - faar samlet en Skare sammen, stormer de mod Vladivostock for at styrte Bolshevikerne.

Det var det, der skete Natten mellem den tredivte og enogtredivte Marts."

Man ser hende for sig, den tyveårige i den grimme, men kønsneutrale spejderuniform - og tankerne går videre til journalistiske arvtagere som Puk Damsgaard og Simi
Jan, tørklædeklædte i Syrien, og Mathilde Kiemer med skudsikker hjelm i Ukraine.

Damesiden - nej tak!

Turen kunne måske være blevet en flyvende start på en karriere som dagbladsjournalist. Ott lod sig dog ikke ansætte på en avis, selvom Berlingske lokkede; hun ville hellere have sin frihed, for hun var slet ikke færdig med at rejse. Et hurtigt blik på dagbladene i Danmark kunne også afsløre, at der højst var plads til én kvindelig journalist på hver avis - og hun 


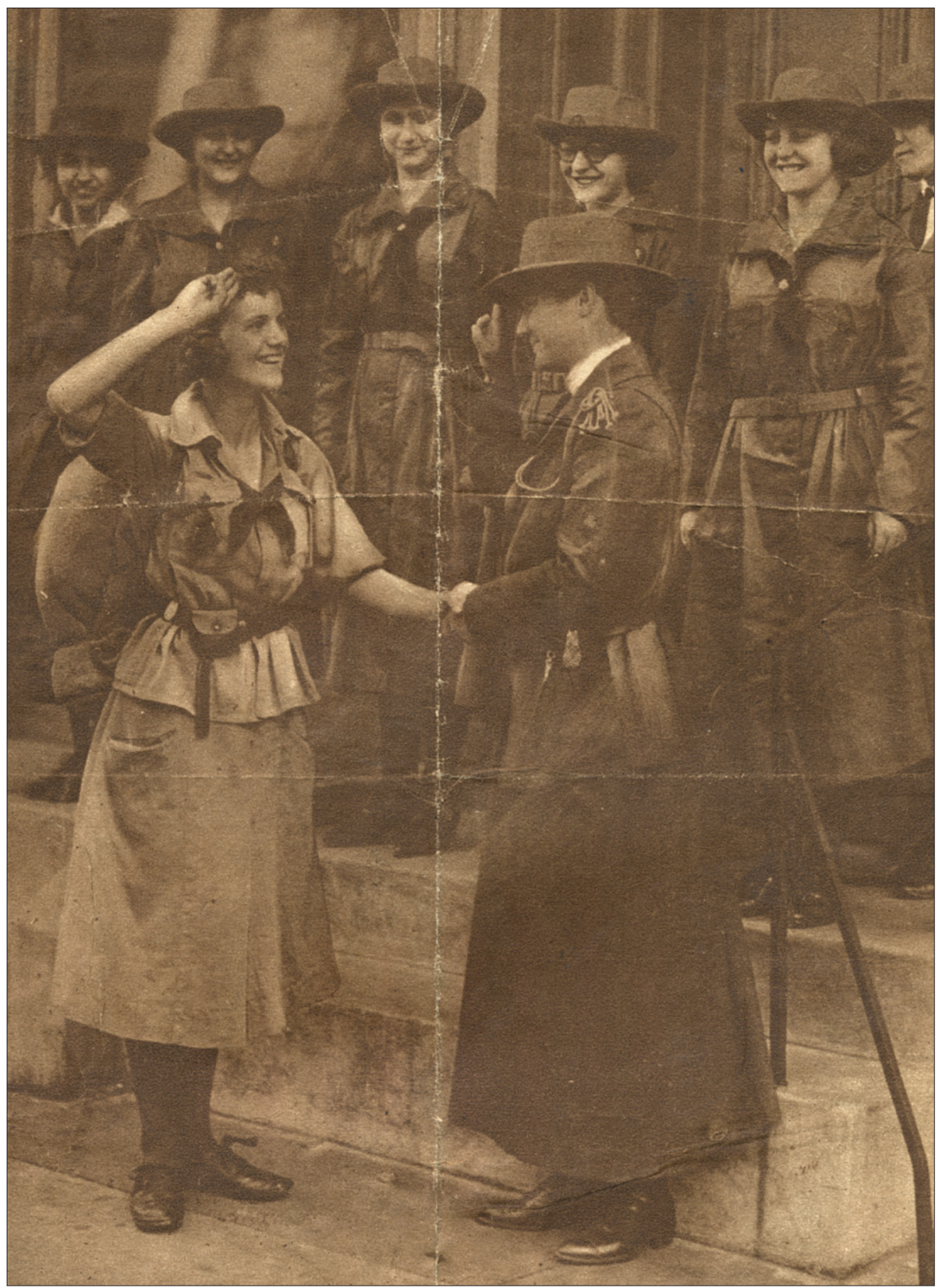

Estrid Ott ankommer til New York oktober 1920. Udklip fra Express, Buffalo N.Y. Avisens billedtekst beretter vantro, at "Captain Ott" ikke berer våben på sin rejse, da hun ønsker at vise, at en piges spejderuniform er tilstrakkelig beskyttelse hvorsombelst i verden! Udklip fra scrapbogen. 
blev altid overladt stof som Hus og Hjem eller Damernes Verden. Ott havde andre planer, og oplevelserne fra Vladivostok blev genbrugt i novellen Fremmed Valuta mange år senere.

Det er en nøgtern og fuldstændigt illusionsløs beretning om en russisk kvinde i Vladivostok, der optræder som kvidrende barnebrud i et ægteskab med en fordrukken svensk industrimand, en "sejrherre" i det kaos, der fulgte i kølvandet på den russiske borgerkrig 1918-20, hvor japanske, tjekkiske, amerikanske og britiske militærstyrker intervenerede. Manden fra 'det høje nord' er, forstår vi, den værdifulde og nødvendige 'valuta', som kvinden betaler med sin seksualitet (novellen er trykt i Et blodrodt Stank, 1943).

\section{En feminist med en plan}

Otts position som solidarisk feminist fejler bestemt ikke noget. Det ser man også i det projekt, der blev hendes vigtigste, det hun især blev kendt for, og det hun kom til at leve af. Hun ville give piger og unge kvinder et alternativ til det traditionelle pigeliv, der var de fleste forundt, et liv, der stort set kun var forberedelse til ægteskab. Hun ville skrive bøger, der kunne inspirere og opruste til et andet liv; bøger, der var anderledes end de sentimentaltinderlige historier, de fleste 'ungpigebøger' var fyldt med. Helt op til 1950'erne var normen i den slags bøger tårevædede beretninger om ulykkelige ungmøer på strenge kostskoler eller som husassistenter hos onde direktørfruer. Men til sidst kom prinsen på den hvide hest, og så var problemerne løst.

Den model var ikke Estrid Otts. Hun skrev om kække og modige pigehovedpersoner, der handlede og færdedes hjemme- vant i den store verden og i den barskeste natur - og det betød, at de 8-16-årige pigelæsere, som lå hende særligt på sinde, fik masser af realoplysninger og praktisk viden om forhold i naturen, om dyrs levevis, og om mulighed for at finde vej og klare sig med få hjælpemidler. Noget der ellers kun kunne findes i drengebøger og i spejderidrætten og spejderlivet.

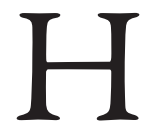
endes mange bøger - mere end 85 titler - var dog ikke nok til at forsørge en familie med fire børn og en mand, der var hjemmegånde, så Ott skrev også journalistiske artikler og drog landet rundt og holdt foredrag om sine rejser og oplevelser i Grønland, Finmarken, Lofoten og Svalbard. Hun var berygtet for at spille de forskellige aviser ud mod hinanden, så hun fik de mest attraktive aftaler og de bedste honorarer. Det var eksempelvis Politiken, der skulle have haft de ugentlige artikler, da hun, udsendt af Grønlands Styrelse, overvintrede 1932-33 med mand og fire små børn i Østgrønland - men Berlingske bød over og fik kontrakten.

Senere vendte Ott tilbage til Politiken og til Viggo Cavling, der nu var redaktør af det berømte tillæg Magasinet. Et kig $i$ avisens honorarprotokoller afslører, at hun alene i regnskabsåret 1935-36 fik 29 artikler eller oversættelser trykt, heriblandt en selvironisk serie om sit liv som bondekone på den nordsjællandske gård, hun og hendes mand ejede i en periode i 1930'rne.

Og så var hun, ikke at forglemme, korrespondent i Finland under Vinterkrigen 1939-40 og under den såkaldte Fortsættelseskrig 1941-44, hvor hun drog rundt med Lotta Svärd, det finske lottekorps, der spillede en aktiv rolle under begge krige. Det kom der både artikler og bøger ud af. 


\section{Modernitetskritik?}

Ott fortsatte hele livet med at hylde spejderbevægelsens pædagogiske principper - learning by doing - i sit liv og i sit store forfatterskab. Hun tilbad maskulin styrke, heltemod, hærdende øvelser og ranke rygge, både som privatperson og i forfatterskabet, og hun var derfor også en dedikeret, livslang beundrer af den karismatiske, monokelbærende Cay Lembcke - uanset hans medlemsskab af det danske nazistparti, DNSAP. Hun hyldede moderskikkelsen i det finske lottekorps og heroiserede krig som renselse. Men hun gjorde også grin med den tyske militærmagt i Danmark under krigen og blev arresteret og forhørt i Dagmarhus. Og hun var aktiv i modstandsbevægelsen og skjulte både jøder og modstandsfolk.

Hun udfordrer med andre ord vores måde at tænke feminisme, frigørelse, mandligt og kvindeligt. Og politik og modernitet, for den sags skyld. Men det er en helt anden historie.

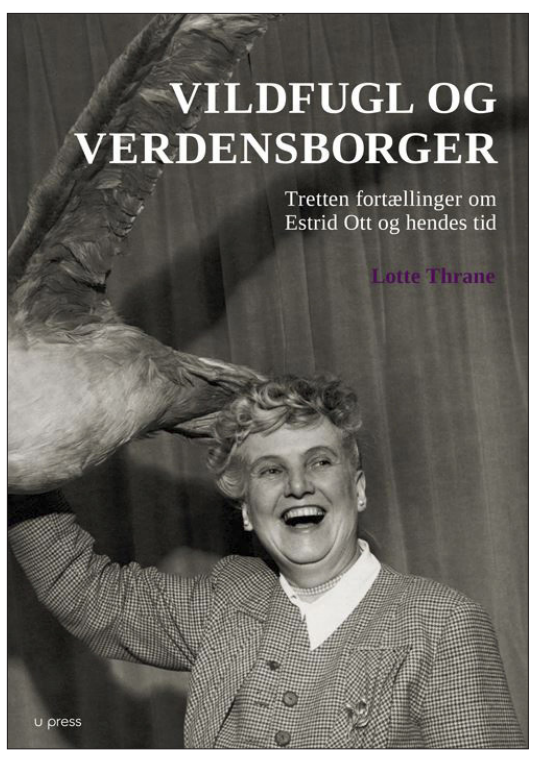

Lotte Thranes kulturbistoriske biografi Vildfugl og verdensborger - Tretten fortællinger om Estrid Ott og hendes tid udkom 4. september 2015.
Estrid Ott (1900-1967) var journalist og forfatter til 85 titler:

Fire voksenbøger, en række småbørnsbøger (f.eks. Bimbi-bøgerne, hvor en legetøjselefant er fortæller) og over 40 "pigebøger", mange med handling fra de arktiske egne. Nisseriget (1917), Kare Chester (1931), BjørneKari (1945) og Chicos lange vandring (1957) udløste henholdsvis kanonisering, nominering og hæderspriser i samtiden, og karakteristiske titler som Da Mor var Dreng (1923), Frida og Fjeldlapperne (1943) og Amik drager ud i verden (1953) kan stadig få lys i øjnene på kvinder over 50 . Drengene læste efter sigende hemmeligt med.

Hun var, da hun døde, den forfatter, der modtog næsthøjeste beløb af bibliotekspengene. 